\title{
Accessory hepatic artery: incidence and distribution
}

\author{
Artéria hepática acessória: incidência e distribuição
}

\author{
Sukhendu Dutta, ${ }^{1}$ Bimalendu Mukerjee ${ }^{2}$
}

\section{Abstract}

Background: Anatomic variations of the hepatic arteries are common. Preoperative identification of these variations is important to prevent inadvertent injury and potentially lethal complications during open and endovascular procedures.

Objective: To evaluate the incidence, extra-hepatic course, and presence of side branches of accessory hepatic arteries, defined as an additional arterial supply to the liver in the presence of normal hepatic artery.

Methods: Eighty-four human male cadavers were dissected using a transperitoneal midline laparotomy. The supra-celiac aorta, celiac axis, and hepatic arteries were dissected, and their trajectories were identified to describe arterial branching patterns.

Results: Normal hepatic arterial anatomy was identified in $95 \%$ of the cadavers and six $(5 \%)$ had accessory hepatic arteries. In five cadavers the accessory hepatic artery followed its course through the fissure for ligamentum venosum, and in one it coursed adjacent to the hepatic artery through the margin of the lesser omentum. One cadaver had a single side branch, which provided arterial blood supply to the left adrenal gland in the absence of any left inferior phrenic artery.

Conclusion: Accessory hepatic artery most often follows the course of the hepatic fissure for ligamentum venosum. Albeit uncommonly found in $5 \%$ of cases, this finding should be identified during open and endovascular procedures to prevent inadvertent injury.

Keywords: Liver-arterial supply, celiac trunk, accessory hepatic artery, suprarenal artery.

\section{Introduction}

Proper identification of anatomic variations within the upper abdomen is essential for surgical and radiological interventions. A wide range of variations has been reported by Weiglein in $1996^{1}$. Pre-operative arterial imaging is of paramount importance to plan open and endovascular procedures involving the upper abdominal organs. ${ }^{2-4}$ Volpe et al. ${ }^{5}$ reported that injuries to hepatic arterial supply are more likely to be involved in pancreaticoduodenectomy, especially in the region of porta hepatis. The hepatic artery originates from the celiac axis in 52 to $76 \%$ of individuals, and the presence of variations of the normal hepatic artery

\section{Resumo}

Contexto: As variações anatômicas das artérias hepáticas são comuns. A identificação pré-operatória dessas variações é importante para prevenir lesão inadvertida e complicações potencialmente letais durante procedimentos abertos e endovasculares.

Objetivo: Avaliar a incidência, o trajeto extra-hepático e a presença de ramos laterais das artérias hepáticas acessórias definidas como um suprimento arterial adicional para o fígado na presença de artéria hepática normal.

Métodos: Oitenta e quatro cadáveres humanos masculinos foram dissecados através de laparotomia mediana transperitoneal. A aorta supracelíaca, o eixo celíaco e as artérias hepáticas foram dissecados, e suas trajetórias foram identificadas para descrever os padrões dos ramos arteriais.

Resultados: Anatomia arterial hepática normal foi identificada em 95\% dos cadáveres, e seis (5\%) tinha artérias hepáticas acessórias. Em cinco cadáveres, a artéria hepática acessória seguia seu trajeto através da fissura para o ligamento venoso, e em um caso a artéria corria adjacente à artéria hepática através da margem do pequeno omento. Um cadáver tinha um ramo unilateral que fornecia sangue arterial para a glândula adrenal esquerda na ausência de qualquer artéria frênica inferior esquerda.

Conclusão: A artéria hepática acessória frequentemente segue o trajeto da fissura hepática para o ligamento venoso. Embora comumente encontrado em $5 \%$ dos casos, esse achado deve ser identificado durante procedimentos abertos e endovasculares para prevenir lesão inadvertida.

Palavras-chave: Suprimento arterial hepático, tronco celíaco, artéria hepática acessória, artéria suprarrenal.

anatomy is found in 32 to $48 \%$ of patients. ${ }^{6-11}$ These variations may predispose patients to inadvertent injury during open surgical procedures or percutaneous interventions. The aim of this study was to describe the frequency and the anatomic course of variations of the normal hepatic artery circulation.

\section{Material and methods}

The present study included 84 male cadavers with height ranging between 158 to $167 \mathrm{~cm}$ and without apparent abnormalities. A midline transperitoneal incision was used to expose the supracolic compartment, and the supraceliac

1. Shri Guru Ram Rai Institute of Medical and Health Sciences. Paten Nagar, Dehradun, India.

2. Vinayak Mission, Pondichery, India.

No conflicts of interest declared concerning the publication of this article.

Manuscript received May 21 2009, accepted for publication Nov 162009.

J Vasc Bras. 2010;9(1):25-27.

Copyright $@ 2010$ by Sociedade Brasileira de Angiologia e de Cirurgia Vascular 
aorta, celiac axis, and its branches were dissected. The common and proper hepatic artery was dissected, and the presence of accessory hepatic artery (AHA) was identified. AHA is defined as an additional arterial supply to the liver in the presence of normal hepatic artery. Special attention was directed to the extra-hepatic course of the hepatic and AHAs and its relationship to adjacent anatomic landmarks.

\section{Results}

The majority of the subjects studied had normal hepatic artery pattern. ${ }^{12,13}$ Only six subjects (5\%) had an AHA distributed in the extrahepatic region (Figure 1).

In five subjects, an AHA followed its course through the fissure for ligamentum venosum (FLV). In one subject, AHA passed along the hepatic artery through the margin of the lesser omentum (LO). AHA was lateral to hepatic artery proper and entered into liver through the porta hepatis. The observations on six subjects showed that one of the subjects showed a solitary branch that was spreading in the subphrenic region. This subject did not show any inferior phrenic artery on its left side. The same artery supplied the apex of the left suprarenal gland (Figure 2).

\section{Discussion}

AHA is defined as an additional artery supplying the liver in the presence of a normal hepatic artery. Occurrence of this condition can be explained by its embryological

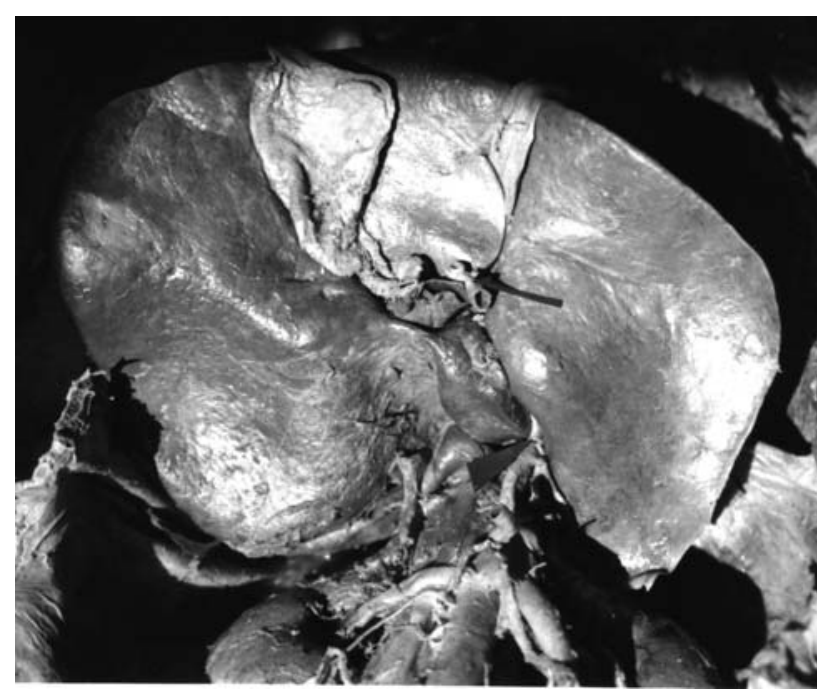

Figure 1 - Accessory hepatic artery (AHA) originates from celiac trunk (CT), passing through fissure for ligamentum venosum (FLV), hepatic artery proper (HAP) passing through porta hepatic, cut end of common hepatic artery (CHA)

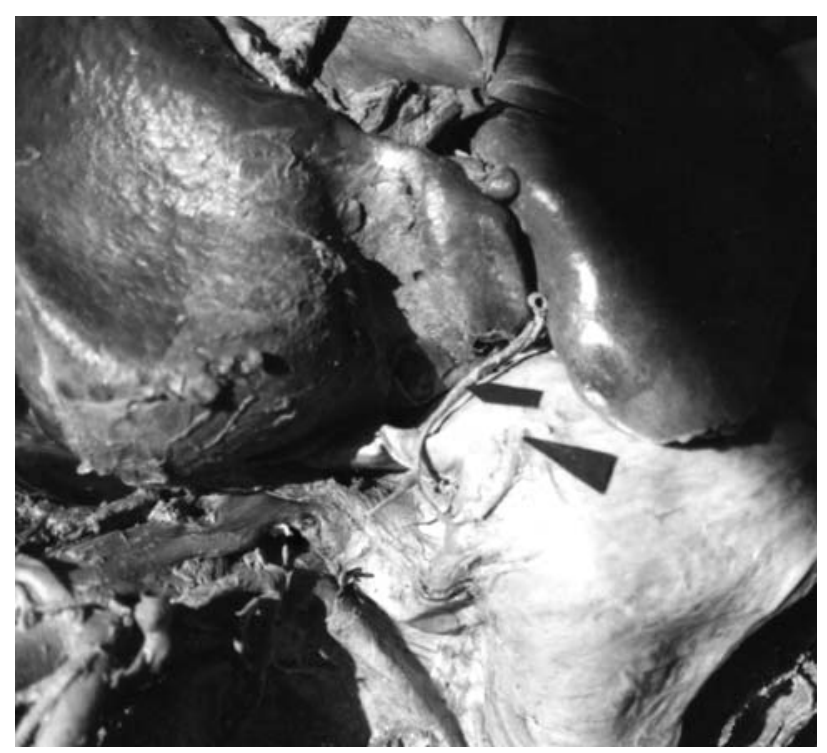

Figure 2 - Accessory hepatic artery (AHA) in the fissure for ligamentum venosum, left inferior phrenic artery (LIPA) originates from AHA, black arrow head shows branches to the inferior surface diaphragm, LIPA continue as left superior suprarenal artery

basis, suggested by Kulesza et al., ${ }^{14}$ according to which there should be presence of sufficient quantities of signaling molecules and growth factors produced by the developing and migrating mammalian cells for the normal development of any viscera. In the event of an improper signaling and incorrect gradient, there may occur visceral anomalies. When an artery does not originates from an orthodox position, being the only supply to a particular lobe, it is called a replaced artery. ${ }^{12,15}$ Origin, occurrence, and importance of accessory and replaced hepatic arteries are well documented by Michels, ${ }^{16}$ Niederhuber et al., ${ }^{17} \mathrm{Ke}-$ meny et al., ${ }^{18}$ Brems et al., ${ }^{19}$ Hiatt et al., ${ }^{3}$ and Braun et al. ${ }^{20}$

The observations of the present study showed less variation in contrast with the earlier reports. ${ }^{3,16-19}$ In the present study, $95 \%$ of the arterial supply was normal in its origin and course from the celiac axis. There was presence of AHA in 5\% of the cases. No replaced hepatic artery was observed. Similar observations were not found in the literature. It is notable that we have observed distinct origin of left inferior phrenic artery (LIPA) from AHA, and LIPA was supplying the upper part of the left suprarenal gland. Though there are case reports in the literature ${ }^{21,22}$ about the presence of AHA in the FLV, in the present study five cases of AHA were found in the FLV and in one case of AHA coursed along with hepatic artery and entered porta hepatis (Table 1). 
Table 1 - Result of occurrence and distribution of accessory hepatic artery $(n=84)$

\begin{tabular}{|c|c|c|c|c|}
\hline Name of the artery & $\%$ & Origin & Course & Extrahepatic branches \\
\hline Normal hepatic artery & 95 & \multirow{2}{*}{$\begin{array}{l}\text { celiac } \\
\text { axis }\end{array}$} & 78 cases, normal & Normal branching pattern \\
\hline Accessory hepatic artery & 5 & & $\begin{array}{l}5 \text { cases were in the FLV and } 1 \text { case was } \\
\text { in the LO }\end{array}$ & $\begin{array}{l}\text { In } 5 \text { cases no branches but in } 1 \text { case } \\
\text { LIPA and SSA }\end{array}$ \\
\hline
\end{tabular}

FLV = fissure for ligamentum venosum; LIPA = left inferior phrenic artery; LO = lesser omentum; SSA = superior suprarenal artery.

Knowledge of anatomical variations in the arterial supply to the liver is necessary for clinical applications. ${ }^{8,23}$ Based on the anatomical findings of the present study, it may be suggested that surgeons and radiologists need to be aware of the presence of AHA in the FLV to avoid serious or fatal complications.

\section{References}

1. Weiglein AH. Variations and topography of the arteries in the lesser omentum in humans. Clin Anat. 1996;9:143-50.

2. Sahani D, Sanjay S, Constantino P, et al. Using multidetector CT for preoperative vascular evaluation of liver neoplasms: technique and results. Am J Roentgenol. 2002;179:53-9.

3. Hiatt JR, Gabbay J, Busutil RW. Surgical anatomy of the hepatic arteries in 1000 cases. Ann Surg. 1994;220:50-2

4. Chuang VP, Wallace S. Hepatic arterial redistribution for intra arterial infusion of hepatic neoplasms. Radiology. 1980;135:295-9.

5. Volpe CM, Peterson S, Hoover EL, Doerr RJ. Justification for visceral angiography prior to pancreaticoduodenectomy. Am Surg. 1998;64:758-61.

6. Santis De M, Ariosi P, Calò GF, Romagnoli R. Hepatic arterial vascular anatomy and its variants. Radiol Med. 2000;100:145-51.

7. Gruttadauria S, Foglieni CS, Doria C, Luca A, Lauro A, Marino IR. The hepatic artery in liver transplantation and surgery: vascular anomalies in 701 cases. Clin Transplant. 2001;15:359-63.

8. Jones RM, Hardy KJ. The hepatic artery: a reminder of surgical anatomy. J R Coll Surg Edinb. 2001;46:168-70.

9. Allen PJ, Stojadinovic A, Ben-Porat L, et al. The management of variant arterial anatomy during hepatic arterial infusion pump placement. 2002;9:875-80.

10. Abdullah SS, Mabrut JY, Garbit V, et al. Anatomical variations of the hepatic artery: study of 932 cases in liver transplantation. Surg Radiol Anat. 2006;28:468-73.

11. Mäkisalo H, Chaib E, Nikos K, Calne R. Hepatic arterial variations and liver-related diseases of 100 consecutive donors. . 2008;6:325-9.

12. Standring S. Gray's anatomy: the anatomical basis of clinical practice. 39th ed. London: Churchill Livingstone; 2005. p. 1218.

13. Sinnatamby CS. Last's anatomy: regional and applied. 11th ed. Edinburgh: Elsevier; 2006. p. 273.

14. Kulesza RJ Jr, Kalmey JK, Dudas B, Buck WR. Vascular anomalies in a case of situs inversus. Folia Morphol. 2007;60:69-73.
15. Skandalakis JE, Skandalakis PN, Skandalakis LJ .Surgical Anatomy and technique: a pocket manual. 2nd ed. New York: Springer-Verlag; 2002. p. 537.

16. Michels NA. Newer anatomy of the liver and its variant blood supply and collateral circulation. Am J Surg. 1962;112:337-47.

17. Niederhuber JE, Ensminger WD. Surgical considerations in the management of hepatic neoplasia. Semin Oncol. 1983;10:135-47.

18. Kemeny MM, Hogan JM, Goldberg DA, et al. Continuous hepatic artery infusion with an implantable pump: problems with hepatic arterial anomalies. Surgery. 1986;99:501-4.

19. Brems JJ, Millis JM, Hiatt JR, et al. Hepatic artery reconstruction during liver transplantation. Transplantation. 1989;47:403-6.

20. Braun MA, Collins MB, Wright P . An aberrant right hepatic artery from the right renal artery: anatomical vignette. Cardiovasc Intervent Radiol. 1991;14:349-51.

21. Pai RS, Hunnargi AS, Srinivasan M. Accessory left hepatic artery arising from common hepatic artery. Indian J Surg. 2008;70:80-2.

22. Plakunta T, Potu BK, Gorantla VR, Vollala VR, Thomas J .Surgical importance of variant hepatic blood vessels: a case report. J Vasc Bras. 2008; 7:84-86.

23. Gordon DH, Martin EC, Kim YH, Kutcher R. Accessory blood supply to the liver from the dorsal pancreatic artery: an unusual anatomic variant. Cardiovasc Radiol. 1978;1:199-201.

Correspondence:

Sukhendu Dutta

Department of Anatomy

Shri Guru Ram Rai Institute of Medical \& Health Sciences

Patel Nagar, Dehradun, 248001 - India

E-mail:dutta8suk@hotmail.com

\section{Author contributions}

Conception and design: SD

Analysis and interpretation: SD

Data collection: SD

Writing the article: SD

Critical revision of the article: SD, BM

Final approval of the article*: SD, BM

Statistical analysis: SD

Overall responsibility: SD

Obtained funding: N/A

* All authors have read and approved the final version of the article submitted to J Vasc Bras. 